\title{
Clinical utility gene card for: Haemochromatosis [HFE]
}

\author{
Manfred Stuhrmann $^{\star, 1}$, Heinz Gabriel ${ }^{2}$ and Stephen Keeney ${ }^{3}$ \\ European Journal of Human Genetics (2010) 18, doi:10.1038/ejhg.2009.245; published online 3 February 2010
}

\section{DISEASE CHARACTERISTICS}

1.1 Name of the disease (synonyms)

Hereditary haemochromatosis (haemochromatosis type 1).

\subsection{OMIM\# of the disease}

235200.

1.3 Name of the analysed genes or DNA/chromosome segments HFE.

1.4 OMIM\# of the gene(s)

235200 .

\subsection{RefSeq NM}

139003.

\subsection{Mutational spectrum}

In European populations, the incidence of C282Y homozygosity in individuals diagnosed with hereditary haemochromatosis ranges from $52 \%$ to $96 \%,{ }^{2}$ with a stronger association seen in Northern European populations, in which the allele frequency is at its highest. Mediterranean and Southern European populations have low $\mathrm{C} 282 \mathrm{Y}$ and $\mathrm{H} 63 \mathrm{D}$ allele frequencies and a corresponding lower association with clinically diagnosed iron overload. ${ }^{3,4}$ Compound heterozygosity for $\mathrm{C} 282 \mathrm{Y}$ and $\mathrm{H} 63 \mathrm{D}$ is associated with up to a further $6 \%$ of European cases ${ }^{2}$ and the remainder have either one or none of the above variants. More than 20 different candidate mutations in HFE associated with the condition have been described; however, their clinical significance and prevalence in different populations is not always known.

\subsection{Analytical methods}

A range of reliable analytical techniques is available for the molecular genetic diagnosis of hereditary haemochromatosis. The most common method for detection of C282Y and H63D remains PCR amplification followed by restriction enzyme digestion. Alternative approaches are available and several commercial suppliers have developed analytical kits.

\subsection{Analytical validation}

Internal validation by testing known mutations and external validation through national or international quality assurance schemes. The Hannover haemochromatosis screening pilot study ${ }^{5}$ has validated several test characteristics (see point 2).
1.9 Estimated frequency of the disease in Europe (incidence at birth ('birth prevalence') or population prevalence) The prevalence of the $\mathrm{C} 282 \mathrm{Y}$ allele in Europe varies from $1.3 \%$ in Italy ${ }^{6,7}$ to $11.4 \%$ in Southern Ireland. ${ }^{8}$ H63D has an allele frequency ranging between $10 \%$ and $20 \%$ in Europe. ${ }^{6}$ Penetrance of risk genotypes is incomplete and is greater in males than in females. Absolute figures for penetrance are difficult to ascertain, owing to variations in individual study design relating to objective criteria for confirming a diagnosis of iron overload and potential ascertainment bias in individual study populations. However, with increasing age, the majority of $\mathrm{C} 282 \mathrm{Y}$ homozygotes will manifest elevated iron indices, but only a small proportion of these (current best estimates indicate 1-2\%) will develop significant clinical symptoms of iron overload. ${ }^{9,10}$ An estimated $50 \%$ of homozygous $\mathrm{C} 282 \mathrm{Y}$ females will show evidence of iron accumulation, usually associated with slower progression to a disease state. ${ }^{7}$

1.10 If applicable, prevalence in the ethnic group of investigated person

C282Y exists in populations of European origin. H63D occurs throughout the world population, but is most common in Europe (see point 1.9).

\subsection{Diagnostic setting}

\begin{tabular}{lll}
\hline & Yes & No \\
\hline A. (Differential) diagnostics & $\Downarrow$ & $\square$ \\
B. Predictive testing & $\bigotimes$ & $\square$ \\
C. Risk assessment in relatives & $\Downarrow$ & $\square$ \\
D. Prenatal & $\square$ & $\square$
\end{tabular}

Comment: Predictive diagnostics only after age 18.

\section{TEST CHARACTERISTICS}

\begin{tabular}{|c|c|c|c|c|}
\hline & \multicolumn{2}{|c|}{ Genotype or disease } & \multirow{2}{*}{$\begin{array}{l}\text { A: True positives } \\
\text { B: False positives }\end{array}$} & \multirow{2}{*}{$\begin{array}{l}\text { C: False negative } \\
\text { D: True negative }\end{array}$} \\
\hline & Present & Absent & & \\
\hline \multicolumn{5}{|l|}{ Test } \\
\hline Positive & $A$ & B & $\begin{array}{l}\text { Sensitivity: } \\
\text { Specificity: }\end{array}$ & $\begin{array}{l}A /(A+C) \\
D /(D+B)\end{array}$ \\
\hline Negative & C & $\mathrm{D}$ & $\begin{array}{l}\text { Positive predictive value: } \\
\text { Negative predictive value: }\end{array}$ & $\begin{array}{l}A /(A+B) \\
D /(C+D)\end{array}$ \\
\hline
\end{tabular}


2.1 Analytical sensitivity (proportion of positive tests if the genotype is present) $97 \% .^{5}$

$98.4 \% .^{11}$

\subsection{Analytical specificity} (proportion of negative tests if the genotype is not present) $100 \% .^{5}$

$99.8 \% .^{11}$

\subsection{Clinical sensitivity}

(proportion of positive tests if the disease is present)

The clinical sensitivity can be dependent on variable factors such as age or family history. In such cases a general statement should be given, even if quantification can only be made case by case.

Greater than $90 \%$ in Northern European populations, where the condition has been clearly defined and other causes of iron overload have been excluded. ${ }^{12}$

\subsection{Clinical specificity}

(proportion of negative tests if the disease is not present)

The clinical specificity can be dependent on variable factors such as age or family history. In such cases a general statement should be given, even if quantification can only be made case by case.

Greater than $99 \% .^{12}$

\subsection{Positive clinical predictive value}

(lifetime risk to develop the disease if the test is positive)

Approximately $1-2 \%$ for clinically significant iron overload. ${ }^{9,10}$

In the range of $20-50 \%$ for symptoms associated with haemochromatosis.

2.6 Negative clinical predictive value (probability not to develop the disease if the test is negative) Assume an increased risk based on family history for a non-affected person. Allelic and locus heterogeneity may need to be considered.

Index case in that family had been tested:

Greater than 99\%.

Index case in that family had not been tested: $98 \%$.

\section{CLINICAL UTILITY}

3.1 (Differential) diagnosis: The tested person is clinically affected (To be answered if in 1.10 'A' was marked)

\subsubsection{Can a diagnosis be made other than through a genetic test?}

\begin{tabular}{|c|c|c|}
\hline No & $\square$ (continue with 3.1.4) & \\
\hline \multirow[t]{7}{*}{ Yes } & $\otimes$ & \\
\hline & Clinically & $凶$ \\
\hline & Imaging & $\begin{array}{l}\text { QUse of magnetic resonance imaging } \\
\text { (low sensitivity) or SQUID (high cost) }\end{array}$ \\
\hline & Endoscopy & $\square$ \\
\hline & Biochemistry & $凶$ \\
\hline & Electrophysiology & $\square$ \\
\hline & Other (please describe) liver biopsy & \\
\hline
\end{tabular}

3.1.2 Describe the burden of alternative diagnostic methods to the patient Liver biopsy carries a degree of risk to the patient and tends to be used in the context of prognosis rather than diagnosis. It may be omitted if supporting biochemical and genetic data indicating iron overload are available. It may be performed if the genetic diagnostic test does not explain the clinical presentation of the patient in the presence of elevated biochemical iron indices. In some circumstances liver biopsy of $\mathrm{C} 282 \mathrm{Y}$ homozygotes may be warranted. ${ }^{13}$

3.1.3 How is the cost effectiveness of alternative diagnostic methods to be judged?

Available studies suggest that HFE genotyping is cost effective. ${ }^{12}$ Costs will differ depending on the progression of the disease at diagnosis. An early genetically proven diagnosis may avoid later alternative and expensive diagnostics and/or management strategies.

3.1.4 Will disease management be influenced by the result of a genetic test?

\begin{tabular}{|c|c|c|}
\hline No & $\square$ & \\
\hline \multirow[t]{4}{*}{ Yes } & $\otimes$ & \\
\hline & $\begin{array}{l}\text { Therapy (please } \\
\text { describe) }\end{array}$ & Venesection therapy \\
\hline & $\begin{array}{l}\text { Prognosis (please } \\
\text { describe) }\end{array}$ & $\begin{array}{l}\text { A normal life expectancy is restored if venesection } \\
\text { therapy is implemented prior to sufficient iron } \\
\text { accumulation to cause organ damage. }{ }^{14} \text { In individuals } \\
\text { in whom iron overload has progressed, the prognosis } \\
\text { varies depending on the degree of organ damage at } \\
\text { diagnosis, but venesection will often reduce symptoms } \\
\text { such as fatigue, abdominal pain and liver dysfunction. } \\
\text { Cirrhosis, arthropathy and hypogonadism do not } \\
\text { improve after venesection. }{ }^{13}\end{array}$ \\
\hline & $\begin{array}{l}\text { Management } \\
\text { (please describe) }\end{array}$ & $\begin{array}{l}\text { Investigation at diagnosis for any organ involvement } \\
\text { that may require specialist care. Venesection therapy } \\
\text { may be performed or organised in a variety of follow-up } \\
\text { care settings, which may follow different local } \\
\text { recommendations across Europe. }\end{array}$ \\
\hline
\end{tabular}

3.2 Predictive setting: The tested person is clinically unaffected but carries an increased risk based on family history

(To be answered if in 1.10 ' $\mathrm{B}$ ' was marked)

\subsubsection{Will the result of a genetic test influence lifestyle and preven-} tion?

Yes.

If the test result is positive (please describe):

Regular monitoring of biochemical iron indices should be implemented. If these indices reach critical thresholds, therapeutic venesections will be indicated. Where local blood donation guidelines permit, [0]asymptomatic individuals with a risk genotype may prevent progression towards iron overload by donating blood regularly.

If the test result is negative (please describe):

No preventative measures are required. Appropriate counselling of individual to explain their low-risk genotype.

3.2.2 Which options in view of lifestyle and prevention does a person at-risk have if no genetic test has been done (please describe)? Regular biochemical follow-up (ferritin, transferrin saturation), venesection therapy if abnormal test results are obtained.

3.3 Genetic risk assessment in family members of a diseased person (To be answered if in 1.10 ' $\mathrm{C}$ ' was marked) 
3.3.1 Does the result of a genetic test resolve the genetic situation in that family?

Yes.

\subsubsection{Can a genetic test in the index patient save genetic or other tests in family members?}

No.

3.3.3 Does a positive genetic test result in the index patient enable a predictive test in a family member?

Yes.

\subsection{Prenatal diagnosis}

(To be answered if in 1.10 ' $\mathrm{D}$ ' was marked).

\subsubsection{Does a positive genetic test result in the index patient enable a prenatal diagnostic?}

Not applicable.

\section{IF APPLICABLE, FURTHER CONSEQUENCES OF TESTING}

Please assume that the result of a genetic test has no immediate medical consequences. Is there any evidence that a genetic test is nevertheless useful for the patient or his/her relatives? (Please describe)

The genetic diagnosis of haemochromatosis has clinical validity for both index cases and their relatives. Appropriate predictive genetic testing of family members should establish their risk for the condition. Additional benefits may be realised with regard to lifestyle planning. In the Hannover pilot study of haemochromatosis screening, $70 \%$ of participants mentioned that they had gained personal benefits from the study. ${ }^{15}$

\section{CONFLICT OF INTEREST}

The authors declare no conflict of interest.

\section{ACKNOWLEDGEMENTS}

This work was supported by EuroGentest, an EU-FP6 supported NoE, contract number 512148 (EuroGentest Unit 3: 'Clinical genetics, community genetics and public health', Workpackage 3.2).

1 Feder JN, Gnirke A, Thomas W et al: A novel MHC class I-like gene is mutated in patients with hereditary haemochromatosis. Nat Genet 1996; 13: 399-408.

2 Hanson EH, Imperatore G, Burke W: HFE gene and hereditary hemochromatosis: a HuGE review. Human Genome Epidemiology. Am J Epidemiol 2001; 154: 193-206.

3 Pointon JJ, Wallace D, Merryweather-Clarke AT, Robson KJ: Uncommon mutations and polymorphisms in the hemochromatosis gene. Genet Test 2000; 4: 151-161.

4 Papanikolaou G, Politou M, Terpos E, Fourlemadis S, Sakellaropoulos N, Loukopoulos $D$ : Hereditary hemochromatosis. HFE mutation analysis in Greeks reveals genetic heterogeneity. Blood Cells Mol Dis 2000; 26: 163-168.

5 Stuhrmann M, Strassburg C, Schmidtke J: Genotype-based screening for hereditary haemochromatosis. I: Technical performance, costs and clinical relevance of a German pilot study. Eur J Hum Genet 2005; 13: 69-78.

6 Merryweather-Clarke AT, Pointon JJ, Jouanolle AM, Rochette J, Robson KJ: Geography of HFE C282Y and H63D mutations. Genet Test 2000; 4: 183-198.

7 Worwood $\mathrm{M}$ : Inherited iron loading: genetic testing in diagnosis and management. Blood Rev 2005; 19: 69-88.

8 Byrnes V, Ryan E, Barrett S, Kenny P, Mayne P, Crowe J: Genetic hemochromatosis, a Celtic disease: is it now time for population screening? Genet Test 2001; 5: 127-130.

9 Beutler E, Felitti VJ, Koziol JA, Ho NJ, Gelbart T: Penetrance of 845G > A (C282Y) HFE hereditary haemochromatosis mutation in the USA. Lancet 2002; 359: 211-218.

10 McCune CA, Al-Jader LN, May A, Hayes SL, Jackson HA, Worwood M: Hereditary haemochromatosis: only $1 \%$ of adult HFE C282Y homozygotes in South Wales have a clinical diagnosis of iron overload. Hum Genet 2002; 111: 538-543.

11 Palomaki GE, Haddow JE, Bradley LA, Richards CS, Stenzel TT, Grody WW: Estimated analytic validity of HFE $\mathrm{C} 282 \mathrm{Y}$ mutation testing in population screening: the potential value of confirmatory testing. Genet Med 2003; 5: 440-443.

12 Bryant J, Cooper K, Picot J et al: A systematic review of the clinical validity and clinical utility of DNA testing for hereditary haemochromatosis type 1 in at-risk populations. J Med Genet 2008; 45: 513-518.

13 Tavill AS: Diagnosis and management of haemochromatosis. AASLD Practice Guidelines. Hepatology 2001; 33: 1321-1328.

14 Niederau C, Fischer R, Purschel A, Stremmel W, Haussinger D, Strohmeyer G: Long term survival in patients with hereditary haemochromatosis. Gastroenterology 1996; 110: 1107 .

15 Stuhrmann M, Hoy L, Nippert I, Schmidtke J: Genotype-based screening for hereditary hemochromatosis: II. Attitudes toward genetic testing and psychosocial impact - a report from a German pilot study. Genet Test 2005; 9: 242-254. 